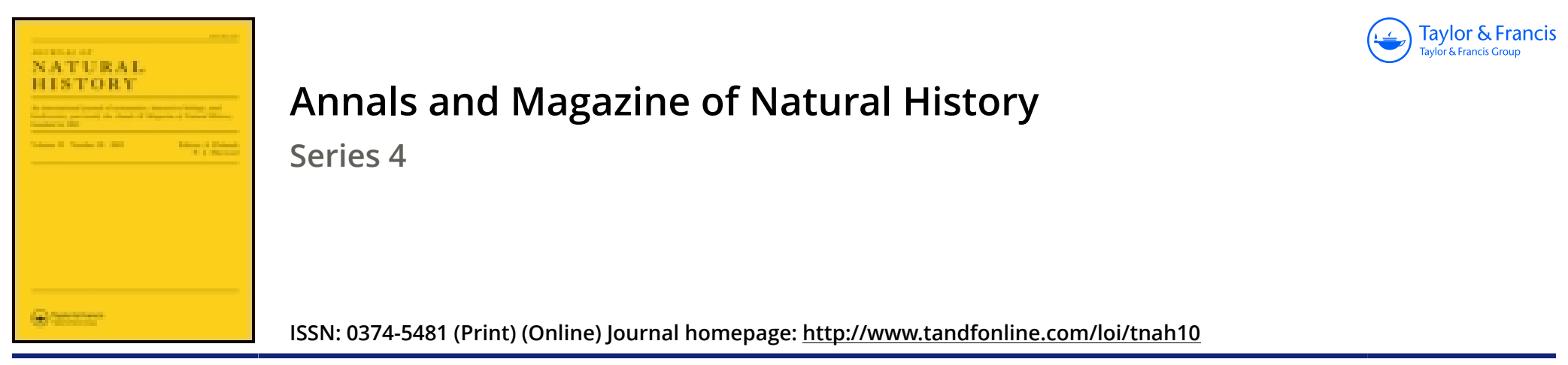

\title{
On the geographical distribution of Schizocephala, a genus of Mantidæ
}

\section{J. Wood-Mason Esq.}

To cite this article: J. Wood-Mason Esq. (1876) On the geographical distribution of Schizocephala, a genus of Mantidæ, Annals and Magazine of Natural History, 18:107, 439-439, DOI: $10.1080 / 00222937608682072$

To link to this article: http://dx.doi.org/10.1080/00222937608682072

电 Published online: 15 Oct 2009.

Submit your article to this journal $\sqsubset \pi$

Џ Article views: 5

Q View related articles 두 
any mention of them. These brushes occurred in numerous species belonging to the following genera:-Metalleutica, Charadodis, Humbertiella, Micromantis, Pseudomantis, Archimantis, Mesopteryx, shasmatomantis, Euchomena, Gonypeta, Hierodula, Mantis, Tenodera, Iris, Phespis, Fischeria, Schizocephala, Hymenopus, Creobrota, Paroxypilus, Popa, Deroplatys, Oxypilus, Phyllocrania, Ceratomantis, Hestias, Gongylus, Empusa, Blepharis, \&c., and probably universally throughout the whole group, although he had examined none of the American species, which, however, were hardly likely to prove an exception to the rule.-Proceedings of the Asiatic Society of Bengal, June 1876.

\section{On the Geographical Distribution of Schizocephala, a Genus of} Mantidæ. By J. Wood-Masor, Esq.

The author states that, so far from being a peculiarly African form, as it is considered to be by M. do Saussure in his recent monograph of the family, the remarkable genus Schizocephala is one of the most widely distributed, not only of Mantidx but of insects, in India-and, in support of his statement, gives a long list of localities from which he has received either perfect or immature examples of the (?) single species S. bicornis, viz. the Karakpur hills in Behar, Devapur and Chánda in the Central Provinces, Kaladgi in the Bombay presidency, Kachh, Ceylon, Murshidabad and Calcutta in Bengal, Pegu, \&c., and quotes the old entomologist Stoll, who describes and figures examples from Tranquebar and China, and Professor Westwood's 'Arcana Entomologica,' in which it is referred to as an Asiatic form. Finally, he concludes either that the locality given by M. de Saussure is erroneous, or that that author's specimens, if really from South Africa, represent a second species of the genus.-Proceedings of the Asiatic Society of Bengal, June 1876.

On the Capture of Rattlesnakes, and on the Association of these Serpents with a small Owl and a little Marmot. By M. A. Tréctu.

During my journey in North America, I traversed in 1848 a region situated to the west of Arkansas, where rattlesnakes are very common. I took several of them, which $I$ sent to the museum ; the following year $I$ also sent some from Texas. Having remarked that, after making themselves heard, they had little disposition to fly at persons a little way from them, I conceived the idea of taking them in the following manner. I attached a thread to the end of the ramrod of my gun, and made a slip-knot at its free extremity : I then went to the snake, which I had heard or which had been pointed out to me by the Osages with whom I travelled; I excited it; and when it raised itself up, threatening and hissing, I passed my running knot round its neck and pulled it up. The snake did not then make any movement or any effort to disengage itself, but remained straight as a stick. It was easy to kill it. Those which I sent to the Natural-History Museum at Paris were taken in this way, which other travellers may find useful. 